\title{
Hypoxia-induced In Vivo Sickling of Transgenic Mouse Red Cells
}

\author{
Edward M. Rubin, ${ }^{*}$ H. Ewa Witkowska, ${ }^{*}$ Elizabeth Spangler," Peter Curtin," Bertram H. Lubin,” \\ Narla Mohandas," and Shirley M. Clift* \\ *Divisions of Cell and Molecular Biology, and Research Medicine, Lawrence Berkeley Laboratory, University of California, \\ Berkeley, California 94720; ${ }^{\ddagger}$ Children's Hospital, Oakland Research Institute, Oakland, California 94609; \\ and ${ }^{\S}$ Department of Medicine, University of California, San Francisco, California 94143
}

\begin{abstract}
To develop an animal model for sickle cell anemia, we have created transgenic mice that express a severe naturally occurring human sickling hemoglobin, Hb S Antilles. Due to its low solubility and oxygen affinity, $\mathrm{Hb} S$ Antilles has a greater propensity to cause red cell sickling than $\mathrm{Hb} S$. To make transgenic animals that express a high level of $\mathrm{Hb} S$ Antilles, the erythroid-specific DNAse I hypersensitive site II from the human $\beta$-globin cluster was linked independently to the human $\alpha$ 2-globin gene and to the $\beta^{S}$ Antilles gene. Embryos were injected with both constructs simultaneously and seven transgenic mice were obtained, three of which contained both the human $\alpha$ and the human $\beta^{S}$ Antilles transgene. After crossing the human transgenes into the mouse $\beta$-thalassemic background a transgenic mouse line was derived in which approximately half the $\beta$-globin chains in the murine red cells were human $\beta^{\text {S Amtilles. Deoxy- }}$ genation of the transgenic red cells in vitro resulted in extensive sickling. An increase of in vivo sickling was achieved by placing these transgenic mice in a low oxygen environment. This murine model for red cell sickling should help to advance our understanding of sickle cell disease and may provide a model to test therapeutic interventions. (J. Clin. Invest. 1991. 87:639647.) Key words: hemoglobin $S$ Antilles • animal model • sickle cell anemia $\bullet$ hemoglobin polymerization
\end{abstract}

\section{Introduction}

A transgenic mouse model for sickle cell anemia would be valuable in the analysis of factors that initiate red cell sickling in the whole organism, in the study of the pathophysiological consequences of sickling, and in the development of experimental approaches for treatment. Prior attempts at creating such a model have included the introduction of the human $\beta^{8}-(1)$ and both the human $\alpha$ - and $\beta^{s}$-globin genes $(2,3)$ into the mouse genome. The transgenic mouse with the highest levels of $\mathrm{Hb} \mathrm{S}$ in its red cells ( $>80 \%$ of red cell hemoglobin was $\mathrm{Hb} \mathrm{S}$ ) was described by Greaves et al. (2). Although complete deoxygenation resulted in $100 \%$ of red cells from this animal to sickle in vitro, only $0.1 \%$ of red cells sickled in vivo. Analysis of the animal revealed normal somatic development, no obvious manifestations of disease, and no evidence of hemolytic ane-

\footnotetext{
Address reprint requests to Dr. Edward M. Rubin, Lawrence Berkeley Laboratory, 1 Cyclotron Road, 74-157, Berkeley, CA 94720.

Received for publication 9 February 1990 and in revised form 30 August 1990
}

J. Clin. Invest.

(c) The American Society for Clinical Investigation, Inc.

0021-9738/91/02/0639/09\$2.00

Volume 87, February 1991, 639-647 mia despite the amount of $\mathrm{Hb} \mathrm{S}$. The failure of this mouse to exhibit signs of significant in vivo sickling, taken in conjunction with prior analyses of the mechanism regulating hemoglobin polymerization, suggests that criteria for significant in vivo sickling to occur may need to include the following: $(a)$ that the pathological sickling hemoglobin molecules be present at sufficiently high levels or have sufficiently low solubility such that polymerization and sickling will occur in the presence of murine hemoglobin $(1,4)$, and $(b)$ that the human hemoglobin have an oxygen affinity that will favor its existence in the deoxygenated form in murine red cells.

Hemoglobin S Antilles (Hb S Antilles) ${ }^{1}$ is a human sickling variant that, unlike $\mathrm{Hb} \mathrm{S}$, results in significant red cell sickling, anemia, and vaso occlusion in heterozygote carriers (A/S Antilles) (5). Erythrocytes of carriers of the $\mathrm{Hb} \mathrm{A} / \mathrm{S}$ Antilles trait sickle at an oxygen partial pressure similar to that which induces sickling in $\mathrm{Hb} \mathrm{S} / \mathrm{C}$ disease. The $\beta^{\mathrm{s} \text { Antilles }}$-globin chain of the $\mathrm{Hb} \mathrm{S}$ Antilles molecule contains two mutations, $\mathrm{Glu}_{6} \rightarrow$ $\mathrm{Val}_{6}$ (the $\beta$-chain mutation responsible for sickle cell anemia) and $\mathrm{Val}_{23} \rightarrow \mathrm{Ile}_{23}(5)$. These two mutations result in the decreased solubility and lower oxygen affinity of $\mathrm{Hb} \mathrm{S}$ Antilles compared with $\mathrm{Hb} \mathrm{S}$. (For purified $\mathrm{Hb} S$ Antilles and $\mathrm{Hb} S$ the minimal gelling concentration is $11 \mathrm{~g} / \mathrm{dl}$ and $18.4 \mathrm{~g} / \mathrm{dl}$, and the $P_{s 0}$ is $9 \mathrm{~mm} \mathrm{Hg}$ and $5.5 \mathrm{mmHg}$, respectively.) Red cells of transgenic mice expressing high levels of human globin transgenes also contain highly soluble murine hemoglobin (7-9). The oxygen affinity of the murine hemoglobin is significantly lower than that of $\mathrm{Hb} \mathrm{S}$ but not that of $\mathrm{Hb} \mathrm{S}$ Antilles (6). These observations suggest that $\mathrm{Hb} \mathrm{S}$ Antilles may be a better candidate for producing in vivo red cell sickling in transgenic mice than $\mathrm{Hb} \mathrm{S}$.

Several studies have indicated that dominant control regions containing erythroid specific DNase I hypersensitive sites that flank the human $\beta$-globin cluster play a pivotal role in determining the level of expression of globin genes in erythroid cells (7-12). The ability to link these erythroid dominant control regions to globin genes in transgenic mice has enabled several investigators to achieve high level expression of human globin genes in mouse red cells. Recently, Curtin et al. (12) have cloned a small DNA fragment that spans one of these regions, located $54 \mathrm{~kb}$ upstream of the $\beta$-globin gene. Linkage of this DNA fragment, designated erythroid specific hypersensitive site II (HS II), to the human $\beta$-globin gene results in high level erythroid specific expression of human $\beta$-globin in transgenic mice (12).

To maximize the likelihood of creating transgenic mice with red cells that sickle in vivo, we cloned the human $\beta^{\text {S Antilles }}$ gene and coinjected it with the human $\alpha 2$-globin gene, each

1. Abbreviations used in this paper: $\mathrm{Hb} \mathrm{S}$ Antilles, hemoglobin $\mathrm{S}$ Antilles; HS", hypersensitive site II; ISC, irreversibly sickled cells. 
linked to HS II, into fertilized mouse eggs. Mice expressing both human genes were derived. The transgenic mouse red cells contain hybrid mouse $\alpha$ /human $\beta^{\text {s Antilles }}$, hybrid human $\alpha /$ mouse $\beta$, authentic human S Antilles, and authentic mouse hemoglobin molecules. To raise the ratio of human $\beta^{\mathrm{S} \text { Antilles }}$ to mouse $\beta$-globin chains we crossed the human $\alpha$ and $\beta^{S}$ Antilles transgenes into the $\beta$-thalassemic mouse background. Approximately half the $\beta$-globin chains in red cells from the resulting transgenic/ $\beta$-thalassemic mice were $\beta^{\mathbf{S} \text { Antilles }}$. Deoxygenation of the transgenic/ $\beta$-thalassemic red cells resulted in significant sickling in vitro, and placement of the animals in an hypoxic environment increased in vivo sickling.

\section{Methods}

DNA constructs. A size-selected Hind III library prepared from DNA of

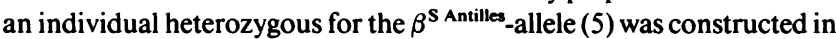
the bacteriophage Charon 30 (13). A human $\beta$-globin probe (1.9-kb Bam HI genomic fragment) was used to screen the library (14) and the $\beta$-globin inserts from the identified lambda clones were subcloned in pUC18. Normal $\beta$ and mutant $\beta^{\text {s Antilles-alleles were first distinguished }}$ by the absence of the codon 6 Mst II site in the latter (15). To further characterize the $\beta$-globin clones four allele-specific 19-bp oligonucleotides $\left(\beta^{\text {S Antilles }}\right.$-codon 6 Glu $\rightarrow$ Val mutation: $5^{\prime}$ TGACTCCTGTGG-

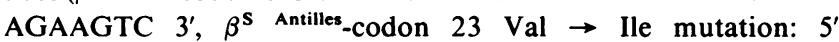
GTGGATGAAATTGGTGGTG 3 ', normal $\beta$-codon $6: 5^{\prime}$ TGACTCCTGAGGAGAAGTC 3 ', normal $\beta$-codon 23:5' GTGGATGAAGTTGGTGGTG $3^{\prime}$ ) were used as probes. After ${ }^{32} \mathrm{P}$ end labeling (16) the various allele-specific oligonucleotides were individually hybridized to the 7.8-kb Hind III $\beta$-globin insert separated from vector sequences on a $1 \%$ agarose gel as described by (17).

The $\beta^{\text {s Antilles }}$-construct injected into fertilized mouse eggs consisted of a $5.0-\mathrm{kb}$ Bgl II fragment containing the $\beta^{\text {S Antilles }}$ gene ligated adjacent to an 800 -bp DNA fragment containing HS II (12). The $\alpha$-globin construct that was coinjected with the $\beta^{\mathbf{S} \text { Antilles }}$ gene was composed of a $1.5-\mathrm{kb}$ Pst I fragment containing the human $\alpha 2$-globin gene (18) adjacent to HS II (Fig. 2).

Production of transgenic mice. The human $\alpha$ - and $\beta^{\text {S Antilles-globin }}$ gene constructs were separated from cloning vector sequences by agarose gel electrophoresis and electroelution. The fragments were further purified by passage through an Elutip D column (Schleicher and Schuell, Inc., Keene, $\mathrm{NH}$ ) followed by ethanol precipitation. A $2-\mu \mathrm{g} / \mathrm{ml}$ DNA solution containing an equal molar ratio of the $\alpha$ - and $\beta^{\mathbf{s} \text { Antilles }}$ globin genes was injected into the male pronuclei of Swiss Webster fertilized eggs (Bantin and Kingman, Inc., Fremont, CA). Transgenic founder animals and their transgenic offspring were identified by Southern blot analysis of tail DNA as described by Hogan et al. (19) The human $\alpha$-probe was a $1.5-\mathrm{kb}$ Pst I fragment containing the entire $\alpha$-globin gene while the human $\beta$-probe was a 1.9-kb Bam HI fragment that includes the $5^{\prime}$ end of the human $\beta$-globin gene.

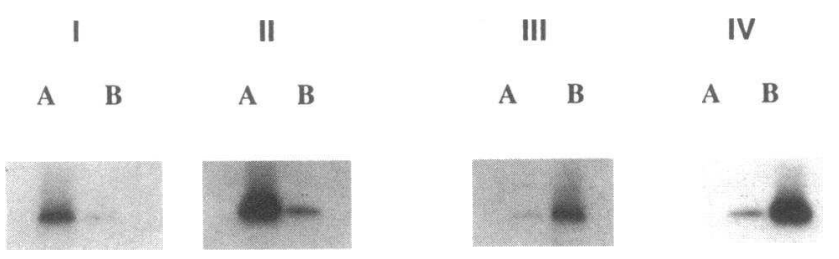

Figure 1. Allele-specific oligonucleotide hybridizations. $\beta^{\mathrm{S} \text { Antilles. }}$ clone, $A$, and a normal $\beta$ clone, $B$, were hybridized to the allelespecific 19-bp oligonucleotide probes for the $(I) \beta^{\text {Antilles }}$-codon 6

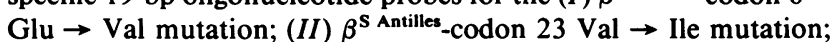
(III) normal $\beta$-codon 6; and (IV) normal $\beta$-codon 23.
Genetic crosses. The homozygous $\beta$-thalassemic mice $\left(\mathrm{Hbb}^{\text {th-1 }} /\right.$ $\left.\mathrm{Hbb}^{\text {th-1 }}\right)(20)$ were the kind gift of Dr. Raymond Popp at the Oak Ridge National Laboratory, Oak Ridge, TN. Mice homozygous for the $\mathrm{Hbb}^{\mathrm{th}-1}$ allele and transgenic for the human $\alpha$ - and $\beta^{\text {s Antilles }}$ genes (transgenic/ $\beta$-thalassemic) were generated by crossing transgenic animals with $\mathrm{Hbb}^{\text {th-1 }} / \mathrm{Hbb}^{\text {th-1 }}$ mice, selecting the transgenic offspring, and backcrossing with $\mathrm{Hbb}^{\text {th-1 }} / \mathrm{Hbb}^{\text {th-1 }}$ mice. The $\mathrm{Hbb}^{\text {th-1 }} / \mathrm{Hbb}^{\text {th-1 }}$ mice were identified by the presence of $\beta^{\text {min }}$ and the absence of $\beta^{\text {maj }}$ mouse $\beta$-globin chains by reverse-phase HPLC.

Globin chain analysis. The globin chains and their tryptic fragments were separated by reverse-phase HPLC. Hemoglobin was run on a C-4 $(1 \times 25 \mathrm{~cm}, 300$ A pore, $5-\mu \mathrm{m}$ particle size) column (Vydac, Hesperia, CA) at a flow rate of $1.7 \mathrm{ml} / \mathrm{min}$. A modified nonlinear gradient was used to develop the column (21). Tryptic fragments were prepared from the isolated human globin chains and separated by reverse-phase HPLC (22). Evaporated HPLC fractions were analyzed in a glycerol:thioglycerol (1:1) $0.1 \mathrm{~N} \mathrm{HCl}$ matrix by liquid secondary ion mass spectrometry on a VG 30-250 quadrupole mass spectrometer (VG Biotech Ltd., Altrincham, UK). The average molecular mass analysis of the intact human $\alpha$-and $\beta^{\text {S Antilles }}$-globin chains was determined by electrospray mass spectrometry (23) on a VG Bio-Q mass spectrometer. Mouse globin chains were identified by Triton urea gel electrophoresis of isolated globin chains (24) compared with known controls. The analytical separation of globin chains isolated from transgenic mouse red cells used a Vydac $C 4$ column $(0.46 \times 25 \mathrm{~cm})$ at a flow rate of 1 $\mathrm{ml} / \mathrm{min}$.

Hemoglobin analysis. The hemoglobins present in transgenic/ $\beta$-thalassemic red cells were separated by ion exchange HPLC (25) on a Synchropak CM $300(0.46 \times 10 \mathrm{~cm})$ column (SynChrom, Inc., Lafayette, IN) or a TSK CM-5 PW column $(0.75 \times 7.5 \mathrm{~cm}, 10-\mu \mathrm{m}$ particle size) (Toyo Soda Manufacturing Co., Ltd., Tokyo, Japan). The composition of each hemoglobin species was determined by first isolating the hemoglobin and then determining its globin chain composition by reverse phase HPLC.

Deoxygenation of red cells. Deoxygenation was performed by blowing humidified nitrogen through a test tube containing $10 \mu \mathrm{l}$ of fresh mouse blood in $1 \mathrm{ml}$ of PBS at $4^{\circ} \mathrm{C}$ for $40 \mathrm{~min}$. The sealed deoxygenated sample was then placed at $37^{\circ} \mathrm{C}$ for $40 \mathrm{~min}$ followed by fixation with $100 \mu \mathrm{l}$ of a deoxygenated $1.5 \%$ glutaraldehyde solution. Reoxygenation involved uncapping the sealed deoxygenated tube just before fixation, swirling the sample to promote contact with air for $5 \mathrm{~min}$, and then adding the glutaraldehyde fixative.

Analysis of mice subjected to hypoxia. Transgenic and control mice were placed in a hypobaric chamber for $10 \mathrm{~d}$. The chamber provided a high altitude environment equivalent to $22,000 \mathrm{ft}(0.42 \mathrm{~atm})$ and an $\mathrm{FiO}_{2}$ of $8.4 \%$. Before and after the 10-d hypoxic exposure blood from individual mice was sampled and analyzed at the ambient $\mathrm{FiO}_{2}$ of

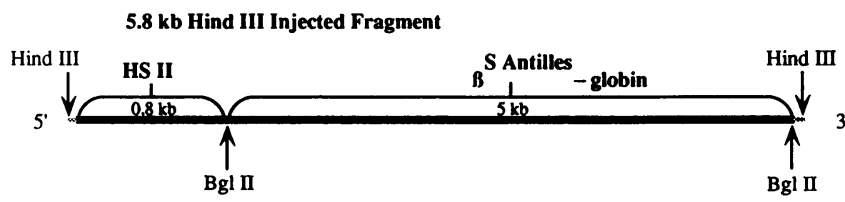

2.7 kb Pvu II Injected Fragment

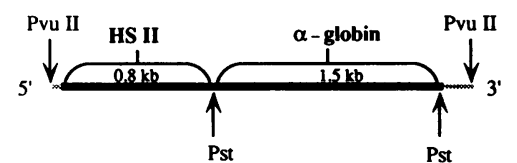

Figure 2. $\alpha$ and $\beta^{\text {s Antilles }}$-globin gene constructs. The human $\alpha 2$-globin gene was used in the $\alpha$-globin construct while a $\beta^{\text {s Antiles }}$-globin gene isolated from an individual heterozygous for this mutation, was used for the $\beta$-globin construct. Both globin genes are in the same orientation as the $5^{\prime}$ HS II-containing DNA fragment. 


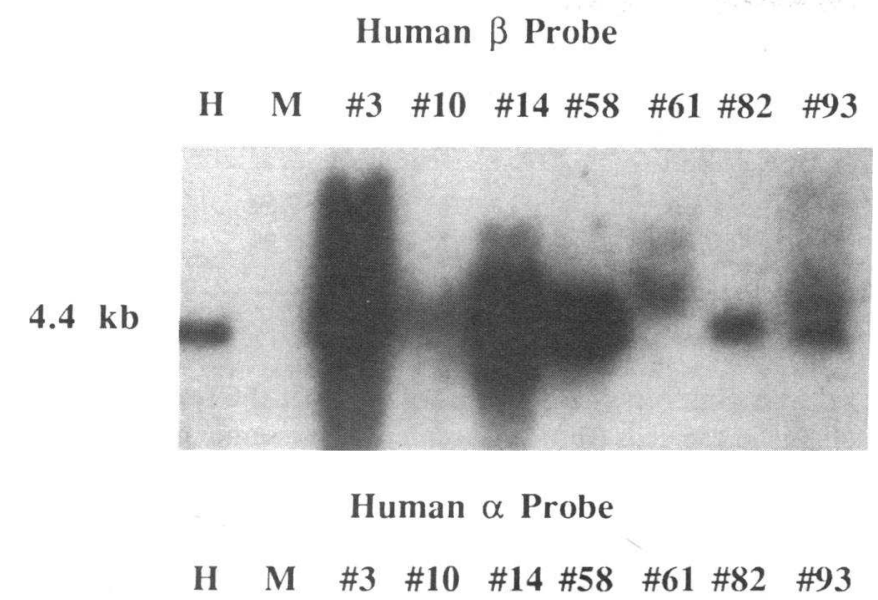

$1.5 \mathrm{~kb}$

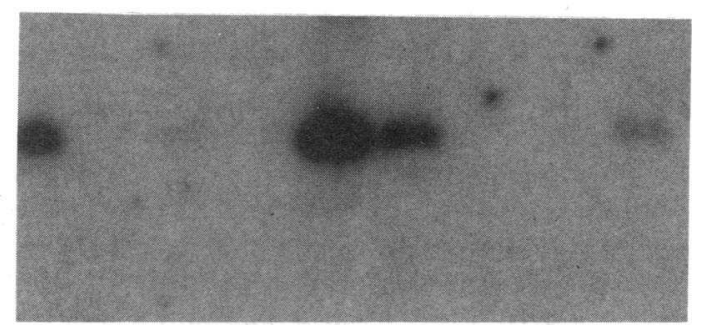

Figure 3. Southern blot analysis of Pst I restriction endonuclease digested DNA from a human control, $H$, a mouse control, $M$, and the seven founder transgenic animals hybridized to human $\alpha$ and $\beta$ probes. Pst I digestion of human control genomic DNA releases 4.4 and 1.5-kb DNA fragments containing $\alpha$ - and $\beta$-globin sequences, respectively.

$20.0 \%$. To quantify the volume distribution of red cells before and after hypoxic exposure the volume distribution of red cells from the various animals was analyzed on an $\mathrm{H}^{*} 1$ blood cell analyzer (Technicon Instruments Corp., Tarrytown, NY). This instrument measures volume of individual isovolumetrically sphered red blood cells (26). To isolate a population of dense cells for morphological analysis, $50 \mu \mathrm{l}$ of blood in a dilute suspension was gently layered above a five step discontinuous Stractan gradient that consisted of $1-\mathrm{ml}$ fractions spanning a density range of 1.074 to $1.120 \mathrm{~g} / \mathrm{ml}$ in equal increments (27). The filled tube was centrifuged in an SW 27 rotor (Beckman Instruments, Inc., Fullerton, CA) at $20,000 \mathrm{rpm}$ for $30 \mathrm{~min}$ at $15^{\circ} \mathrm{C}$. Red cells from the most dense bottom layer were isolated fixed with glutaraldehyde and viewed at $\times 400$.

\section{Results}

Production of transgenic mice with human $\alpha$ - and $\beta^{\text {S Antilles }}$-globin genes. Six $\beta$-globin clones were derived from screening of a 500,000 clone recombinant library constructed from the DNA of an individual heterozygous for the $\beta^{s}$ Antilles allele (5). The codon 6 mutation in the $\beta^{\text {s Antilles }}$ gene results in the loss of an Mst II restriction site. Digestion of the six $\beta$-globin clones isolated from the library with Mst II indicated that two of the six contained the $\beta^{\text {S Antilles }}$ allele (data not shown). This result was confirmed by the appropriate hybridization of these clones to oligonucleotide probes specific for the two mutations that distinguish the mutant $\beta^{\mathrm{S} \text { Antilles }}$ allele from the normal $\beta$-globin allele (Fig. 1).

The human $\alpha$ and $\beta^{\text {S Antilles }}$ globin gene constructs that were coinjected into fertilized mouse eggs are shown in Fig. 2. Southern blot analysis of DNA from pups derived from these
Table I. Hematological Indices

\begin{tabular}{lcccr}
\hline & Hematocrit & MCV & MCHC & Reticulocytes \\
\hline Normal mouse control & $47.4 \pm 1.0$ & $48.0 \pm 0.2$ & $33.4 \pm 0.1$ & $2.1 \pm 0.31$ \\
Transgenic/ $\beta$-thalassemic & $45.9 \pm 0.8$ & $44.4 \pm .07$ & $33.5 \pm 0.3$ & $2.9 \pm 0.57$ \\
$\beta$-thalassemic control & $28.8 \pm 1.3$ & $39.7 \pm 1.3$ & $29.3 \pm 0.3$ & $10.8 \pm 0.16$ \\
& & & & \\
\hline
\end{tabular}

injections, using both human $\alpha$-and $\beta$-globin probes, identified seven transgenic founder animals containing human globin genes. Both human $\alpha$ and $\beta^{\text {s Antilles }}$ sequences were present in three of the mice while the remaining four transgenic animals contained just the $\beta^{S}$ Antilles transgene (Fig. 3). Hybridizing the human $\alpha$-probe to Pst I digests of control human genomic DNA and that of the transgenic founder animals results in a $1.5-\mathrm{kb}$ band. Hybridizing the human $\beta$-probe to Pst I digests of the same DNA results in a 4.4-kb band in the human control lane and several bands in lanes containing DNA from the transgenic animals. These hybridization bands that differ between founder animals result from the fact that the injected

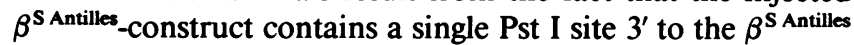
coding sequence and $3.8 \mathrm{~kb}$ away from the $3^{\prime}$ end of the construct. Therefore the size of the released human $\beta^{\text {S Antilles }}$-containing fragment can vary depending upon whether the $5^{\prime}$ Pst I site is derived from an adjacent human $\alpha$-globin construct, $\beta^{S \text { Antilles }}$ construct, or murine genomic DNA in whose midst the $\beta^{S \text { Antilles }}$ construct integrated. The greater number of

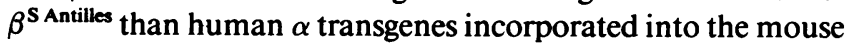
genome may be explained by the observation that blunt ended DNA fragments, such as the human $\alpha$-globin construct, are less efficiently integrated into the mouse genome than DNA fragments with cohesive ends, such as the injected $\beta^{\mathbf{S} \text { Antilles }}$ construct (28).

Among the transgenic mice containing both human globin transgenes the highest and near equivalent levels of the human globin chains were present in red cells from founder animals 58 and 14. The following studies were performed on 58 and its offspring. This animal contained approximately 4 copies of the

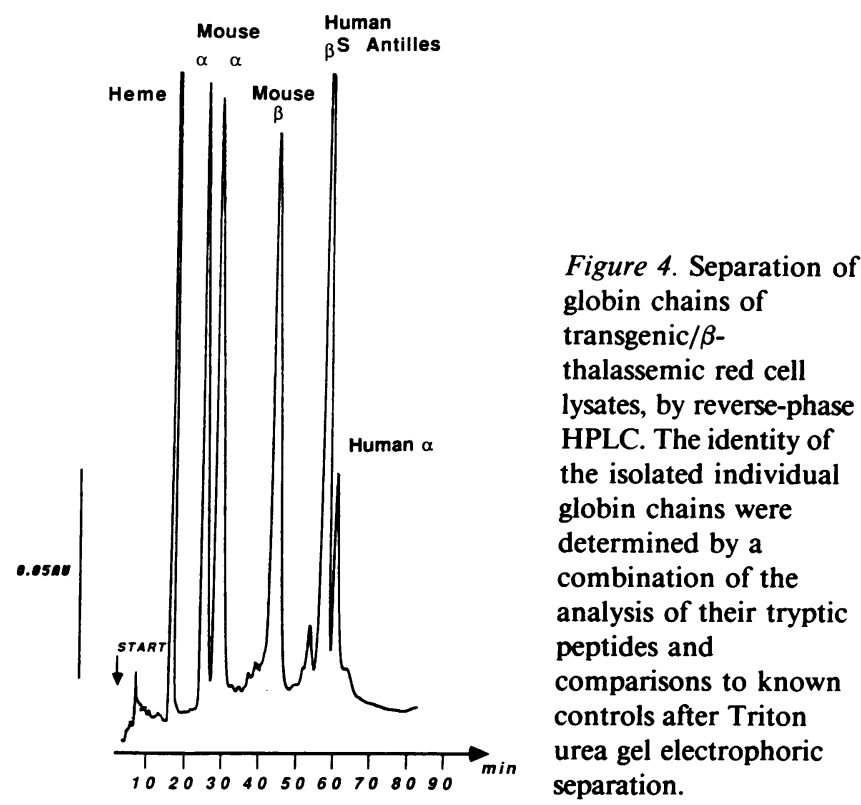




\begin{tabular}{|c|c|c|c|c|c|c|c|}
\hline & & & & $\mathrm{H} \alpha_{2} \mathrm{H} \beta_{2}^{\text {SAnt }}$ & $\mathrm{M} \alpha_{2} \mathrm{H} \beta_{2}^{\text {S Ant }}$ & $\mathbf{H} \alpha_{2} \mathbf{M} \beta_{2}$ & $\mathbf{M} \alpha_{2} \mathbf{M} \beta_{2}$ \\
\hline & $\alpha / \beta$ & H $\alpha /$ Total $\alpha$ & $\mathbf{H} \beta^{\text {SAnt }} /$ Total $\beta$ & Total Hb & Total Hb & Total $\mathbf{H b}$ & Total $\mathrm{Hb}$ \\
\hline 58 Transgenic founder & 1.0 & $9.0 \%$ & $13.7 \%$ & $5.5 \%$ & $7.8 \%$ & $7.5 \%$ & $79.5 \%$ \\
\hline 58 Transgenic/ $\beta$-thal & 1.0 & $17.3 \%$ & $49.3 \%$ & $8.3 \%$ & $40.4 \%$ & $5.9 \%$ & $45.4 \%$ \\
\hline
\end{tabular}

human $\alpha$ and 10 copies of the $\beta^{\text {s Antilles }}$ gene. Half the offspring of 58 were transgenic and the copy number of the human transgenes was unchanged over three generations, suggesting that the human transgenes integrated at a single locus in the mouse genome in this transgenic line.

Globin chain and hemoglobin analysis. Red cells from founder animal 58 did not sickle upon deoxygenation. Because a higher ratio of $\beta^{\text {s }}$ - to normal $\beta$-globin chains in human red cells increases the likelihood of hemoglobin polymerization and cell sickling, we attempted to raise the ratio of the human $\beta^{\text {S Antilles }}$-to murine $\beta$-globin chains in the transgenic mouse red cells by crossing the human transgenes from founder animal 58 into a homozygous $\beta$-thalassemic mouse background. Homozygous $\beta$-thalassemic mice have a deletion of two of the four adult $\beta$-globin genes and thus have reduced synthesis of mouse $\beta$-globin chains ( $\alpha$ to $\beta$ ratio of 1:3) (20). Animals designated transgenic/ $\beta$-thalassemic are hemizygous for the transgene locus and homozygous for the mouse $\beta$-thalassemic locus. Normalization of the hematological indices (Table I) and the $\alpha$ to $\beta$ ratio (Table II) of transgenic/ $\beta$-thalassemic mice indicates that expression of the human transgenes corrects the inherent globin chain imbalance and associated anemia of homozygous $\beta$-thalassemic mice. These results are consistent with a previous study in which $\beta$-globin transgenes alone corrected the thalassemic phenotype when introduced into the homozygous $\beta$-thalassemic mouse background (29).

The globin chains in red cells from the transgenic/ $\beta$-thalassemic animals were separated by reverse-phase HPLC (Fig. 4). There are two mouse $\alpha$-globin chains and a single mouse $\beta$-globin chain in these red cells in addition to the human $\alpha$ and $\beta^{\text {S Antilles }}$-globin chains. The human $\beta^{\text {S Antilles }}$-globin chain comprises approximately half the total $\beta$-globin chains, while the

$\Lambda$

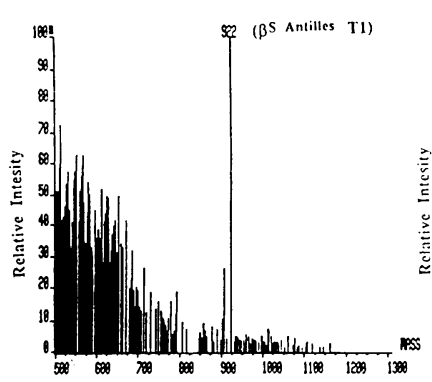

Figure 5. Liquid secondary ion mass spectrometry of the $\beta^{\text {S Antilles. }}$ globin chain tryptic peptides which differ from that of the normal human $\beta$-globin chain. $(A)$ Tryptic peptide 1 with a protonated molecular mass of $922 \mathrm{D}$ as predicted for this tryptic peptide containing a valine at position $6 .(B)$ Tryptic peptide 3 with a protonated molecular mass of $1,328 \mathrm{D}$ as predicted for this tryptic peptide containing an isoleucine at position 23 . human $\alpha$-globin chain comprises $17 \%$ of the total $\alpha$-globin chains in red cells from transgenic/ $\beta$-thalassemic mice. This is a significant increase over the human $\beta^{\text {s Antilles }}$-globin chain (14\%) and $\alpha$-globin chain (9\%) levels of the founder animal 58 (Table II). The relative increase of $\beta^{\text {S Antilles }}$ compared with human $\alpha$-globin chains after transfer of the human transgenes into the $\beta$-thalassemic background may be related to the previously demonstrated increased translational efficiency of $\beta$ - versus $\alpha$-globin mRNA in murine $\beta$-thalassemic red cells (30).

Identification of the human globin chains separated by reverse-phase HPLC was confirmed by preparing tryptic digests of the isolated chains, separating the resulting tryptic peptides and determining their masses by liquid secondary ion mass spectrometry (22). Tryptic digestion of the $\beta^{\text {S Antilles }}$-globin chain isolated from the transgenic mouse red cells resulted in two peptides that differed in molecular mass from their normal human $\beta$-globin chain counterparts (Fig. 5). Tryptic peptide 1 (T1) with a protonated molecular ion mass of $922 \mathrm{D}$ matches the predicted mass of the human $\beta$-globin chain tryptic peptide T1 but with a valine instead of a glutamic acid at position 6 . Tryptic peptide 3 (T3) with a protonated molecular ion mass of $1,328 \mathrm{D}$ matches the predicted mass of the human $\beta$-globin chain tryptic peptide T3 but with an isoleucine instead of a valine at position 23. The second tryptic peptide in Fig. $5 \mathrm{~B}$,

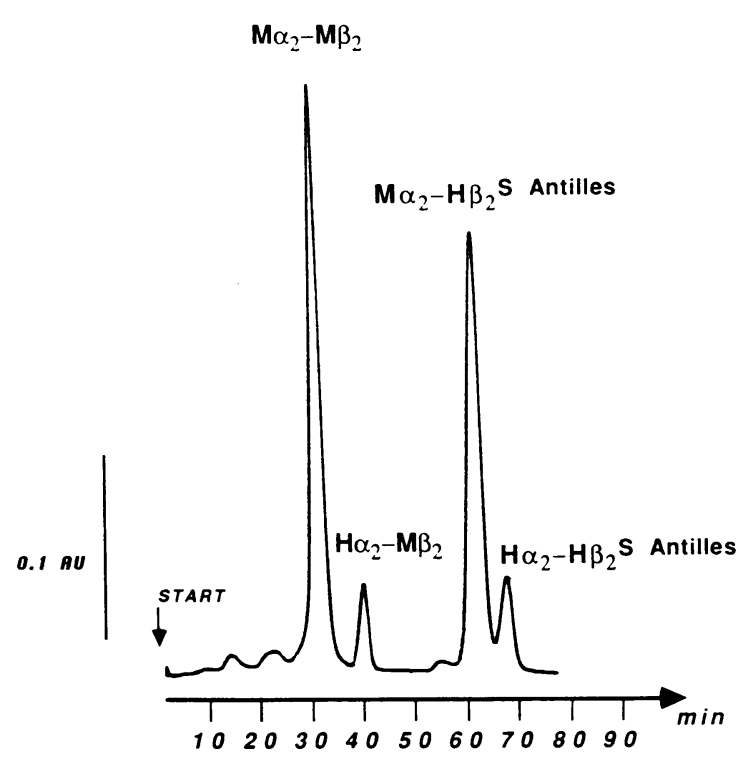

Figure 6. Separation of hemoglobins of transgenic/ $\beta$-thalassemic red cell lysates by ion exchange HPLC. The globin chain composition of each hemoglobin species was determined by isolating individual hemoglobin species by ion exchange HPLC followed by reverse-phase HPLC to determine the globin chain composition. 

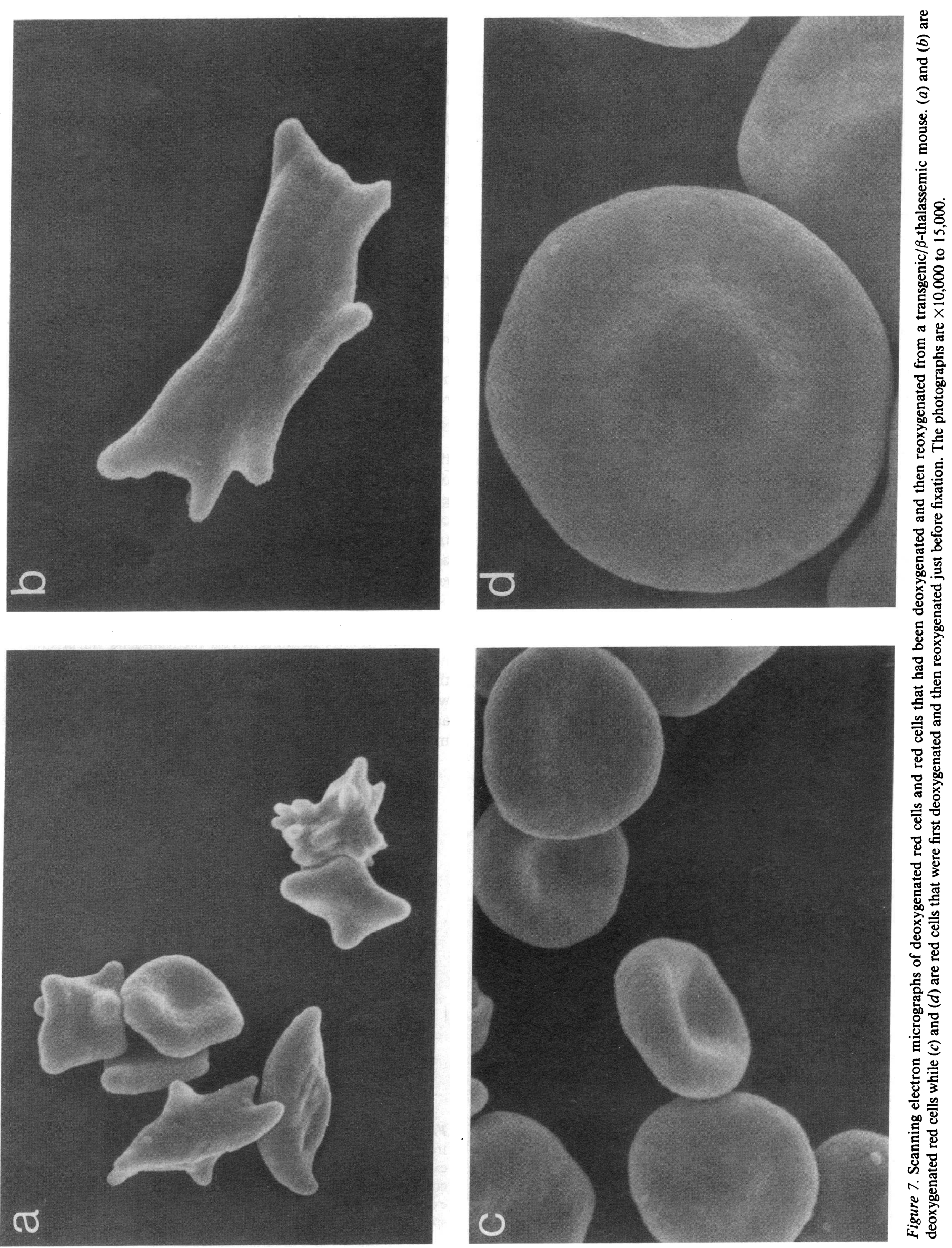
with a protonated molecular ion mass of $1,448 \mathrm{D}$ represents the $\beta$-globin chain tryptic peptide T 14-15 that comigrates on reverse-phase HPLC with the $\beta^{\text {S Antilles }}$ tryptic peptide T3. The masses of the tryptic peptides of the human $\alpha$-globin chain isolated from transgenic mouse red cells were identical to a control $\alpha$-globin sample isolated from human blood (data not shown). The authenticity of the human $\alpha$ - and $\beta^{\text {s Antilles }}$-globin chains in mouse red cells was further confirmed by measurements of the molecular masses of intact chains. Measured by electrospray mass spectrometry (23) the average molecular masses of $\beta^{\text {S Antilles }}(15,850.4 \mathrm{D})$ and human $\alpha(15,127.9 \mathrm{D})$ were within $\pm 1.5 \mathrm{D}$ of predicted values.

The hemoglobins present in transgenic/ $\beta$-thalassemic red cells were separated by ion exchange HPLC (Fig. 6). The hybrid mouse $\alpha$ /human $\beta^{\text {s Antilles }}$ hemoglobin (40\%) along with authentic mouse hemoglobin $(46 \%)$ are the two predominant hemoglobin species (Table II). The minor hemoglobin species present in these red cells include authentic human $\mathrm{Hb} \mathrm{S}$ Antilles $(8 \%)$, and a hybrid human $\alpha /$ mouse $\beta$ hemoglobin (6\%). Red cells from the founder animal 58 have a similar level of authentic $\mathrm{Hb} S$ Antilles (6\%) but a reduced level of hybrid mouse $\alpha /$ human $\beta^{\text {S Antilles }}$ hemoglobin (8\%) compared with cells from transgenic/ $\beta$-thalassemic mice (Table II).

Cellular properties. Classical morphologic sickling was observed after deoxygenation in vitro in $\sim 30 \%$ of the transgenic/ $\beta$-thalassemic red cells, while the remaining cells exhibited varying degrees of shape abnormalities (Fig. 7, $a$ and $b$ ). These morphological changes were reversed by reoxygenation of the sample (Fig. 7, $c$ and $d$ ). Deoxygenation of nontransgenic thalassemic red cells or red cells from normal mice did not result in sickling or morphological changes (data not shown).

The possibility of in vivo sickling was suggested by the appearance of occasional irreversibly sickled cells (ISCs) in peripheral blood smears. To determine if hypoxia would increase the number of sickled cells formed in vivo we placed the transgenic/ $\beta$-thalassemic animals in an hypoxic environment. Since a discernible effect of hypoxia on sickling red cells is a change in cell volume, we quantitated cell volume distribution before and after the hypoxic exposure. The volume of sickled red cells is altered following repeated cycles of hemoglobin polymerization, and red cells from individuals with sickle cell disease exhibit a broader than normal volume distribution. This is believed to be the result of an increased number of cells with smaller volumes due to dehydration and larger volumes due to stress erythropoiesis (26).

The volume distribution of red cells from the transgenic and control animals are similar at an ambient $\mathrm{FiO}_{2}$ of $20 \%$ (Fig. $8)$. The normal volume distribution curves of red cells from transgenic/ $\beta$-thalassemic mice are in agreement with the normalization of the hematological indices (Table I) and the $\alpha / \beta$ ratio (Table II) of cells from these transgenic mice compared with red cells from nontransgenic $\beta$-thalassemic mice. Nontransgenic $\beta$-thalassemic red cells have a markedly broadened volume distribution curve (31) that remains largely unchanged after hypoxic exposure (data not shown). After $10 \mathrm{~d}$ at an $\mathrm{FiO}_{2}$ of $8.4 \%$ the volume distribution curve of the transgenic but not that of the normal control mice, broadens. This broadening reflects an increased number of cells with both increased and decreased volumes.

Many ISCs and dense fragmented cells, believed to result from repeated cycles of sickling and unsickling in vivo, are

found in the dense cell fraction of red cells from humans with sickle cell anemia (32). To examine red cells from hypoxic transgenic mice with decreased volume and increased density, we isolated dense cells from four transgenic and four control animals using a Stractan gradient. Several typical fields of dense cells from a transgenic animal after hypoxic exposure are shown in Fig. 9. Consistent with the volume distribution curves, nearly every field of dense red cells from the hypoxic transgenic mice contains several ISCs while, before the hypoxic exposure, the most dense fraction of red cells from these transgenic mice had very few ISCs. No ISCs were seen in control mice before or after hypoxic exposure.

\section{Discussion}

In this study we have created transgenic mice containing hu$\operatorname{man} \alpha$-and $\beta^{\text {s Antilles }}$-globin genes. Expression of the transgenes results in red cells that sickle upon deoxygenation both in vitro and in vivo, a central feature of sickle cell disease. Our results represent the demonstration of a measureable induction of red cell sickling in an animal in response to hypoxia.

The transgenic animals in our study were homozygous for the mouse $\beta$-thalassemic allele in the mouse $\beta$-globin cluster on chromosome 7 and hemizygous for the human globin transgene at a separate locus in the mouse genome. We have recently bred mice homozygous for the human $\alpha$ and $\beta^{\text {s Antilles }}$ transgene containing locus as well as the mouse $\beta$-thalassemic allele. Animals were judged as being homozygous for the transgene if all their offspring inherited the transgene coupled with Southern blot analysis demonstrating that their transgene-associated hybridization bands were twice as intense as that of animals known to be hemizygous for the transgene. Surprisingly, no significant increase in the ratio of human $\alpha$ and $\beta^{\text {s Antilles }}$ to the total $\alpha$ and $\beta$-globin chains in red cells from these animals was noted. We are now breeding these doubly homozygous animals to generate a renewable source of genetically defined mice for in vivo sickling studies.

Control

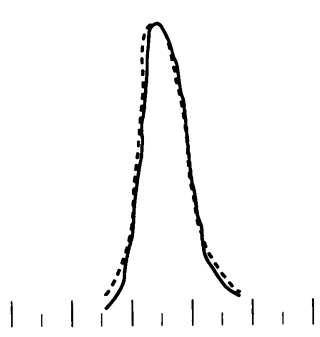

$$
\begin{gathered}
\text { RBC Volume } \\
(0-100 \mathrm{fL})
\end{gathered}
$$

\section{Transgenic}

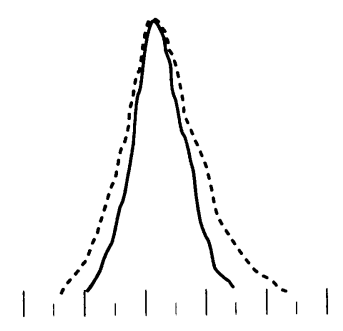

Figure 8. Volume distribution curves of red cells from normal and transgenic/ $\beta$-thalassemic mice before and after a 10 -d hypoxic exposure. These distributions of individual cells were determined by collecting blood samples before and immediately after the hypoxic exposure and determining the volume of individual isovolumetrically sphered $\mathrm{RBCs}$ on a Technicon $\mathrm{H}^{*} 1$ flow cytometer. 

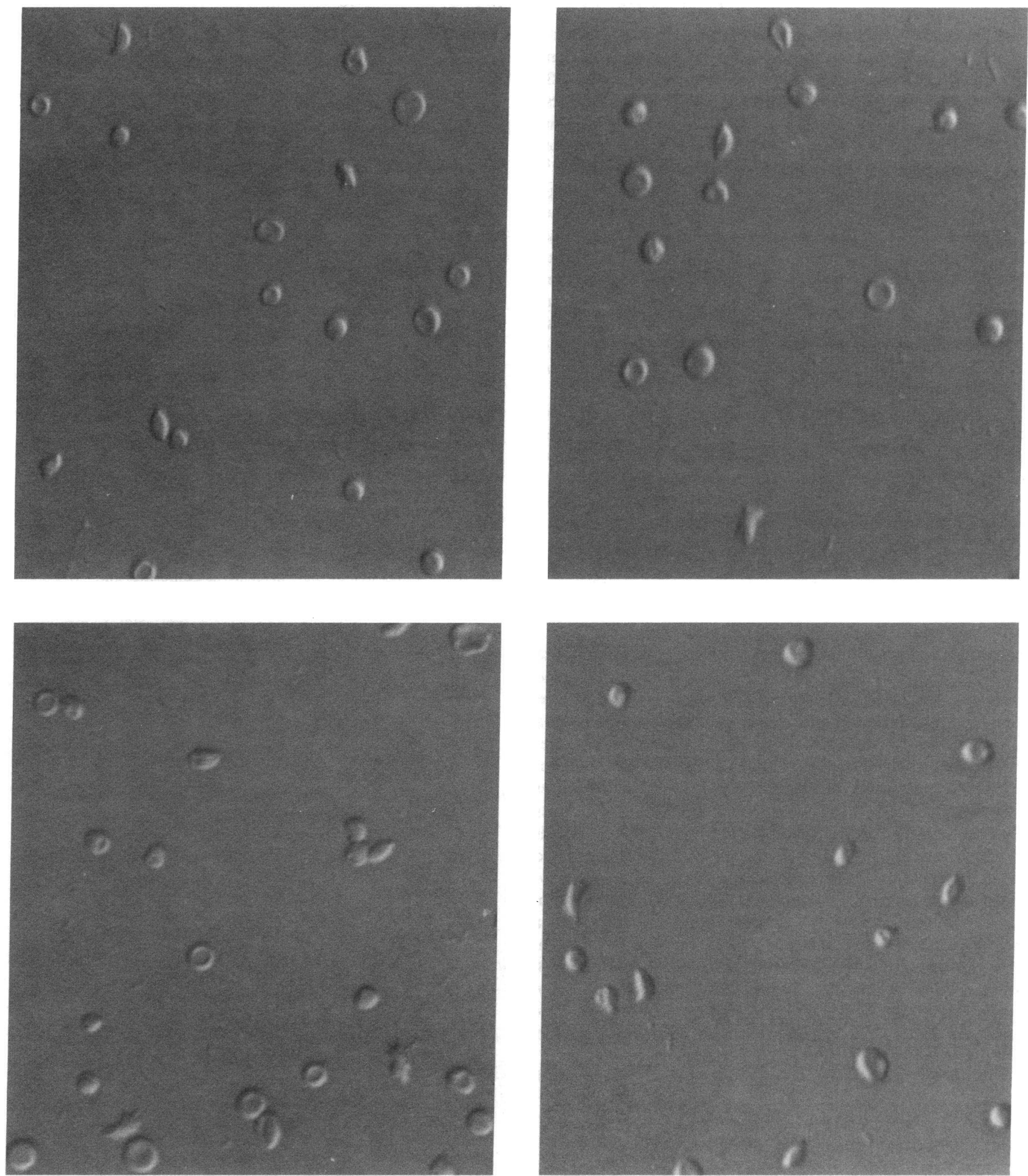

Figure 9. Nomarsky photomicrographs, $\times 400$, of dense cells from a transgenic/ $\beta$-thalassemic mouse immediately after $10 \mathrm{~d}$ of hypoxia. These red cells were isolated from the most dense bottom layer of a Stractan gradient spanning the density range of $1.074-1.120 \mathrm{~g} / \mathrm{ml}$ in equal increments and viewed as wet mounts.

The hemoglobins present in the red cells of the transgenic mice in this study were characterized using the combination of ion exchange HPLC, which separates all the hemoglobin species present in these red cells, followed by reverse-phase HPLC to identify the globin chain composition of each hemoglobin. The predominance of the hybrid mouse $\alpha /$ human $\beta^{\text {s Antilles }}$ hemoglobin in sickling transgenic red cells suggests that this molecule may be participating in hemoglobin polymerization. This 
is further supported by the observation that both in vitro and in vivo sickling occurs in transgenic/ $\beta$-thalassemic red cells containing $8 \% \mathrm{Hb} \mathrm{S}$ Antilles and $40 \%$ hybrid mouse $\alpha$ /human $\beta^{\text {S Antilles }}$ hemoglobin, but does not occur in red cells of the 58 founder animal that contain a similar amount of $\mathrm{Hb} \mathrm{S}$ Antilles (6\%) but significantly less of the hybrid mouse $\alpha$ /human $\beta^{\text {S Antilles }}$ hemoglobin molecule (8\%). Prior in vitro analyses of the kinetics of polymerization of hybrid mouse $\alpha /$ human $\beta^{s}$ Antilles as well as hybrid mouse $\alpha$ /human $\beta^{\text {s }}$ hemoglobin suggested that these mouse/human hybrids would not polymerize (6). However, it should be noted that the $\mathrm{Hb}$ concentrations used in these earlier studies were 250 -fold lower than that found in red cells. This could explain the discrepancy between our findings with intact red cells and the previous solution assays. In two other studies that examined sickling of transgenic red cells containing $\mathrm{Hb} \mathrm{S}(2,3)$, the contribution of the hybrid mouse $\alpha$ /human $\beta^{s}$ molecule to total red cell hemoglobin was not determined.

Of the studies examining the effects of $\mathrm{Hb} \mathrm{S}$ on transgenic red cells $(2,3)$, a mouse with the highest levels of human $\mathrm{Hb} \mathrm{S}$, $84 \%$, was described by Greaves et al. (2). Although significant in vitro sickling of red cells from this animal was observed, other than the observation of $\sim 0.1 \%$ irreversibly sickled cells in peripheral blood smears, normal somatic development and absence of hemolytic anemia suggest that despite the predominance of $\mathrm{Hb} \mathrm{S}$ this animal experienced minimal in vivo sickling. Red cells from another transgenic mouse in this same study, where the ratio of $\mathrm{HbS}$ to total hemoglobin was $35 \%$, did not sickle upon complete deoxygenation in vitro. In a separate study also examining the effect of $\mathrm{Hb} \mathrm{S}$ on transgenic mouse red cells Ryan et al. (3) characterized two lines of transgenic mice where the ratio of $\mathrm{Hb} \mathrm{S}$ to total hemoglobin was $50 \%$. In one line of animals the human $\alpha$ and $\beta^{s}$ transgenes were in a non- $\beta$-thalassemic mouse background while in the second series of animals these transgenes had been moved into a heterozygous mouse $\beta$-thalassemic background. Despite differences of the mouse backgrounds red cells from both series of animals were reported to contain $50 \% \mathrm{Hb} \mathrm{S}$. Less than $1.0 \%$ of red cells from the transgenic non- $\beta$-thalassemic mice sickle in vitro while greater than $90 \%$ of red cells from the transgenic heterozygous $\beta$-thalassemic mice sickle upon complete deoxygenation in vitro. In contrast to the observations of Greaves et al. (2) on a transgenic mouse containing $84 \% \mathrm{Hb} \mathrm{S}$, the transgenic $\beta$-thalassemic mice containing $50 \% \mathrm{Hb}$ S described by Ryan et al. (3) developed mild anemia, reticulocytosis, and splenomegaly. The differing results of these two studies make it difficult to draw conclusions concerning in vivo consequences of $\mathrm{Hb} \mathrm{S}$ in mouse red cells.

With regard to the in vivo consequences of mouse red cells containing human $\alpha$ and $\beta^{\text {s Antilles }}$ globin chains we have been able to conclude in our study that in vivo sickling increases in animals during hypoxia. The transgenic mice we described contain considerably fewer $\alpha$-globin chains in their red cells than the transgenic animals described by Greaves et al. (2) and Ryan et al. (3). This observation, coupled with the lack of information concerning individual globin chain or hybrid hemoglobin levels in the two $\mathrm{Hb} \mathrm{S}$ transgenic mouse studies $(2,3)$, makes it difficult to compare in vivo of properties of human $\alpha$

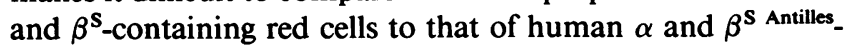
containing cells. The significant in vitro sickling and an inducible in vivo sickling of red cells containing $50 \% \beta^{\text {s Antilles }}$ globin chains but only $8 \% \mathrm{Hb} \mathrm{S}$ Antilles does support our prediction concerning the efficacy of $\mathrm{Hb} \mathrm{S}$ Antilles and $\beta^{\mathbf{S} \text { Antilles }}$ globin chains to foster sickling of mouse red cells both in vitro and in vivo.

The ability to detect and quantitate red cell changes in response to hypoxia in transgenic mice may provide new opportunities for examining red cell sickling in vivo. This system could be used to perform studies that are difficult to do in humans, such as examining the efficacy of experimental antisickling agents. In spite of differences between $\mathrm{Hb} \mathrm{S}$ and $\mathrm{Hb} \mathrm{S}$ Antilles, the need for an animal model for sickle cell anemia, the lack of which has long hindered the study of this disease, may in part be met by this transgenic mouse model.

\section{Acknowledgments}

We thank Y.W. Kan for support during the initial aspects of this work, D. Liu for help with cloning HS II, B. Green (VG Masslab, Altrincham, UK) for performing the Electrospray MS, C. Shackleton for support in all mass spectrometric studies, and K. Kleman, K. Andrews, and D. Kumar for providing excellent technical assistance.

This work was supported by National Institutes of Health grants HL-20985-12, HL-31579, R0-121061, and HL-27059; National Research Service Award training grant HL-07279; and Shared Instrumentation grant 03300 (for VG-30-250). This research was conducted at the Lawrence Berkeley Laboratory (Department of Energy contract DE-AC03-76SF00098 to the University of California) and Children's Hospital Oakland Research Institute.

\section{References}

1. Rubin, E. M., R. Lu, S. Cooper, N. Mohandas, and Y. W. Kan. 1988. Introduction and expression of the human $\beta$-globin gene in transgenic mice. Am. J. Hum. Genet. 42:585-591.

2. Greaves, R. G., P. Fraser, M. A. Vidal, M. J. Hedges, D. Roper, L. Luzzatto, and F. Grosveld. 1990. A transgenic mouse model for sickle cell disorder. Nature (Lond.). 343:183-185.

3. Ryan, T. M., T. Townes, M. P. Reilly, T. Asakura, R. Palmiter, R. Brinster, and R. Behringer. 1990. Human sickle hemoglobin in transgenic mice. Science (Wash. DC). 247:566-568.

4. Bunn, H. F., and B. G. Forget. 1986. Hemoglobin: Molecular, Genetic and Clinical Aspects. W. B. Saunders Company, Philadelphia. 690 pp.

5. Monplaisir, N., G. Merault, C. Poyart, M. D. Rhoda, C. Craescu, M. Vidaud, F. Galacteros, Y. Blouquit, and J. Rosa. 1986. Hemoglobin S Antilles: a variant with lower solubility than hemoglobin $\mathrm{S}$ and producing sickle cell disease in heterozygotes. Proc. Natl. Acad. Sci. USA. 83:9363-9367.

6. Rhoda, M. D., C. Domenget, M. Vidaud, J. Bardakdjian-Michau, P. Rouyer-Fessard, J. Rosa, and Y. Beuzard. 1989. Mouse $\alpha$ chains inhibit polymerization of hemoglobin induced by human $\beta^{\mathbf{S}}$ or $\beta^{\text {S Antilles }}$ chains. 1988. Biochim. Biophys. Acta. 952:208-212.

7. Ryan, T. M., R. R. Behringer, N. C. Martin, T. M. Townes, R. D. Palmiter, and R. L. Brinster. 1989. A single erythroid-specific DNase I super-hypersensitive site activates high levels of human $\beta$-globin gene expression in transgenic mice. Genes \& Dev. 3:314-323.

8. Behringer, R. R., T. Ryan, M. Reilly, T. Asaura, R. Palmiter, R. Brinster, and T. Townes. 1989. Synthesis of functional human hemoglobin in transgenic mice. Science (Wash. DC). 245:971-973.

9. Hanscombe, O., M. Videl, J. Kaeda, L. Luzzatto, D. R. Greaves, and F. Grosveld. 1989. High-level, erthyroid-specific expression of the human $\alpha$-globin gene in transgenic mice and the production of human hemoglobin in murine erythrocytes. Genes \& Dev. 3:1572-1581.

10. Grosveld, F., G. B. van Assendelft, D. R. Greaves, and G. Kollias. 1987 Position-independent, high-level expression of the human $\beta$-globin gene in transgenic mice. Cell. 51:975-985.

11. Forrester, W. C., U. Novak, R. Gelinas, and M. Grodine. 1989. Molecular analysis of the $\beta$-globin locus activation region. Proc. Natl. Acad. Sci. USA. 86:5439-5443.

12. Curtin, P. T., D. Liu, W. Liu, J. C. Chang, and Y. W. Kan. 1989. Human $\beta$-globin gene expression in transgenic mice is enhanced by distant DNase I hypersensitive site. Proc. Natl. Acad. Sci. USA. 886:7082-7087. 
13. Rimm, D. L., D. Horness, J. Kucera, and F. R. Blattner. 1980. Construction of coliphage lambda Charon vectors with Bam HI cloning sites. Gene (Amst.). 12:301-309.

14. Maniatis, T., E. F. Fritsch, and J. Sambrook. 1982. Molecular Cloning: A Laboratory Manual. Cold Spring Harbor Laboratory, Cold Spring Harbor, NY. 545 pp.

15. Chang, J. C., and Y. W. Kan. 1982. A sensitive new prenatal test for sickle cell anemia. N. Engl. J. Med. 307:30-31.

16. Wallace, R. B. J. Shaffer, R. F. Murphy, J. Bonner, and K. Itakura. 1979. Hybridization of synthetic oligodeoxyribonucleotides to $\psi \chi 174$ DNA: the effect of a single base pair mismatch. Nucleic Acids Res. 6:3543-3557.

17. Conner, B. J., A. A. Reyes, C. Morin, K. Itakura, R. L. Teplitz, and R. B. Wallace. 1983. Detection of the sickle cell $\beta^{s}$-globin allele by hybridization with synthetic oligonucleotides. Proc. Natl. Acad. Sci. USA. 80:278-282.

18. Lau, Y. F., and Y. W. Kan. 1983. Versatile cosmid vectors for the isolation expression, and rescue of gene sequences: studies with the human $\alpha$-globin gene cluster. Proc. Natl. Acad. Sci. USA. 80:5225-5229.

19. Hogan, B. L., F. Costantini, and E. Lacy. 1986. Manipulating the Mouse Embryo: A Laboratory Manual. Cold Spring Harbor Laboratory, Cold Spring Harbor, NY. 332 pp.

20. Skow, L. C., B. A. Burkhart, F. M. Johnson, R. A. Popp, D. M. Popp, S. Z. Goldberg, and W. F. Anderson. 1983. A mouse model for $\beta$-thalassemia. Cell. 34:1043-1052.

21. Shelton, J. B., J. R. Shelton, and W. A. Schroeder. 1984. High performance liquid chromatographic separation of globin chains on a large-pore C4 column. J. Liq. Chromatog. 7:1969-1977.

22. Rahbar, S., T. D. Lee, J. A. Baker, L. T. Rabinowitz, Y. Asmeron, K. Legesse, and H. M. Ranney. 1986. Reverse phase high-performance liquid chromatography and secondary ion mass spectrometry. A strategy for identification of ten human hemoglobin variants. Hemoglobin. 10:379-400.
23. Fenn, J. B., M. Mann, C. K. Meng, S. F. Wong, and C. M. Whitehouse. 1989. Electrospray ionization for mass spectrometry of large biomolecules. Science (Wash. DC) 246:64-71.

24. Alter, B. P., S. C. Goff, M. Gravhy, and T. H. Huisman. 1980. Globin chain electrophoresis: a new approach to the determination of the $\mathrm{G} \gamma / \mathrm{A} \gamma$ ratio in fetal haemoglobin and studies of globin synthesis. Br. J. Haematol. 44:527-534.

25. Wilson, J. B. 1990. Separation of human hemoglobin variants by high performance liquid chromatography. In HPLC of Biological Molecules. Methods and Applications. R. Goodieng and G. Regnier, editors. Marcel Dekker, Inc., New York. 457-472.

26. Mohandas, N., A. Johnson, J. Wyatt, L. Croisille, J. Reeves, D. Tycko, and W. Groner. 1989. Automated quantitation of cell density distribution and hyperdense cell fraction in RBC disorders. Blood. 74:442-447.

27. Clark, M. R., N. Mohandas, S. H. Embury, and B. Lubin. 1987. A simple laboratory alternative to irreversibly sickled cell (ISC) counts. Blood. 70:659-662.

28. Brinster, R. L. H. Y. Chen, M. E. Trumbauer, M. K. Yagle, and R. D. Palmiter. 1985. Factors affecting the efficiency of introducing foreign DNA into mice by microinjecting eggs. Proc. Natl. Acad. Sci. USA. 82:4438-4442.

29. Costantini, F., K. Chada, and J. Magram. 1986. Correction of murine $\beta$-thalassemia by gene transfer into the germ line. Nature (Lond.). 233:11921194

30. Curcio, M. J., P. Kantoff, M. P. Schafer, W. F. Anderson, and B. Safer. 1986. Compensatory increase in levels of $\beta^{\text {minor }}$ globin in murine $\beta$-thalassemia is under translational control. J. Biol. Chem. 261:16126-16131.

31. Rubin, E. M., Y. W. Kan, and N. Mohandas. 1988. Effect of human $\beta^{s}$-globin chains on cellular properties of red cells from $\beta$-thalassemic mice. $J$. Clin. Invest. 82:1129-1133.

32. Shen, S. C., E. M. Fleming, and W. B. Castle. 1949. Studies on the destruction of red blood cells. V. Irreversibly sickled erythrocytes: their experimental production in vitro. Blood. 4:498-504. 